\title{
МОРФОЛОГІЧНІ ЗМІНИ СУДИН ЄМНІСНОЇ ЛАНКИ ГЕМОМІКРОЦИРКУЛЯТОРНОГО РУСЛА ЛЕГЕНЬ МОРСЬКИХ СВИНОК, СЕНСИБІЛІЗОВАНИХ ОВАЛЬБУМІНОМ
}

\section{Запорізький державний медичний університет}

РЕЗЮМЕ. Актуальною проблемою сучасної медицини є реакція мікросудин легень при хронічних алергічних захворюваннях дихальної системи, адже саме від стану судин гемомікроциркуляторного русла залежить повноцінне функціонування тканин та клітин організму.

Мета - вивчити морфологічні зміни судин ємнісної ланки гемомікроциркуляторного русла легень морських свинок, сенсибілізованих овальбуміном.

Матеріал та методи. За допомогою гістологічного, морфометричного та статистичного методів вивчали легені 48 самців морських свинок в умовах експериментального овальбумін-індукованого алергічного запалення, яке моделювали шляхом триразової підшкірної сенсибілізації та наступної 8-денної інтраназальної інгаляції овальбуміном. Для визначення структурної та функціональної перебудови посткапілярних та м'язових венул визначали величину внутрішнього діаметра судин.

Результати. Встановлено загальну закономірність реактивності ємнісної ланки гемомікроциркуляторного русла легень морських свинок при експериментальному овальбумін-індукованому алергічному запаленні, що полягає в структурній та функціональній перебудові посткапілярних та м'язових венул у вигляді збільшення діаметра їх просвіту та проникності їх стінки. Більш виражені морфологічні зміни виявлені в посткапілярних венулах у ранньому періоді розвитку алергічного запалення, що підтверджує максимальний коефіцієнт збільшення діаметра просвіту посткапілярних венул, який спостерігається в 1-ій експериментальній групі, порівняно з контролем, і становить 1,7.

Висновки. Сенсибілізація та інгаляційна алергізація овальбуміном призводять до структурної реорганізації у вигляді вазодилатації посткапілярних та м'язових венул гемомікроциркуляторного русла легень морських свинок, яка має односпрямований стадійний характер в залежності від діаметра судин і тривалості експерименту та $\epsilon$ проявом порушення відновно-адаптаційних процесів гемомікроциркуляції. Найбільш виражені зміни виявляються впродовж раннього періоду розвитку алергічного запального процесу в посткапілярних венулах.

КлючОВІ СловА: венула; мікроциркуляція; експериментальне алергічне запалення; легеня; овальбумін; морська свинка.

Вступ. В останні роки відмічається зростання числа хронічних алергічних захворювань органів дихання, що становить значну медичну та соціальну проблему [1]. Одним із недостатньо досліджених явищ у вивченні морфологічних змін при хронічних алергічних захворюваннях дихальної системи залишається реакція мікросудин легень $[2,3]$. Як відомо, від стану судин гемомікроциркуляторного русла (ГМЦР) залежить повноцінне функціонування тканин та клітин органів. Добре відомі й детально вивчені складні та різноманітні процеси перебудови стінки судин адаптаційного характеру при дії на організм різноманітних чинників [4-6]. При цьому з достатньою впевненістю можна стверджувати, що судинна система - це не один із рівнозначних компонентів сполучної тканини, що забезпечує тільки її кровопостачання і обмінні процеси, а центральна її структура, навколо якої відбуваються різноманітні клітинні процеси в нормі та після впливу на орган різних чинників [7-9]. Ємнісна ланка ГМЦР є важливою ділянкою обміну між кров'ю та інтерстиційною тканиною в нормі та при різних патологічних станах. Протягом розвитку алергічного запального процесу клітини мігрують до місця запалення за- вдяки каскаду взаємопов'язаних клітинних і молекулярних процесів, які включають активацію ендотеліоцитів судин нейрогуморальними та імунними факторами, продукцію ними хемоатрактантів і молекул адгезії [10]. Останні викликають адгезію еозинофілів та базофілів до ендотелію судин і їх трансміграцію через судинний бар'єр і накопичення в периваскулярному просторі. Адгезія і трансміграція запальних клітин у легенях відбувається в посткапілярних венулах [11]. Інші автори постулюють основну роль капілярів як місця рекрутування та міграції клітин запалення в легенях [12]. Дані про реакцію компонентів ГМЦР легень на розвиток алергічного запалення у більшості аспектів суперечливі. Тому встановлення характеру та особливостей перебудови ГМЦР легень за умов розвитку експериментального алергічного запального процесу є одним із пріоритетних завдань сучасної морфології.

Мета - вивчити морфологічні зміни судин ємнісної ланки гемомікроциркуляторного русла легень морських свинок, сенсибілізованих овальбуміном.

Матеріал і методи дослідження. О6'єКтом експериментального дослідження були легені, 
Огляди літератури, оригінальні дослідження, погляд на проблему, випадок з практики, короткі повідомлення котрі вилучені від 48 статевозрілих самців морської свинки масою 450 - 600 г, яких утримували у стандартних умовах віварію Запорізького державного медичного університету. Усі маніпуляції та евтаназію тварин проводили з дотриманням основних принципів роботи з експериментальними тваринами відповідно до положення Європейської конвенції про захист хребетних тварин, які використовуються для експериментальних та інших наукових цілей (Страсбург, 1986 р.). Загальних етичних принципів експериментів на тваринах, ухвалених Першим національним конгресом з біоетики (Київ, 2001 р.), Закону України «Про захист тварин від жорстокого поводження» (від 21.02.2006).

Індукцію алергічного запалення дихальних шляхів здійснювали шляхом підшкірної сенсибілізації та наступної інтраназальної алергізації овальбуміном (OBA). На 1, 7, 14 день експерименту морським свинкам проводилась сенсибілізація - підшкірне введення в міжлопаткову ділянку 0,5 мг овальбуміну (Sigma Chemical Co., США) разом з ад' ювантом - гідроокисом алюмінію, 10 мг (AlumVax Hydroxide vaccine adjuvant, OZ Biosciences Франція), розведених в 1 мл фізіологічного розчину. 321 по 28 день експерименту тваринам проводили інгаляцію ОВА в дозі 10 мг/мл фізіологічного розчину протягом 15 хв/добу за допомогою компресорного інгалятора LD-211C (Little Doctor International, Сингапур) в інгаляційній камері. Для проведення дослідження тварини були поділені на 6 груп (по 8 тварин у кожній групі). Перші чотири групи - це тварини, сенсибілізовані та аероалергізовані ОВА, виведені з експерименту відповідно на 23-у, 30-у, 36-у і 44-у добу після його початку; 5 - контрольна група, тваринам якої вводили підшкірно 1 мл фізіологічного розчину та проводили інгаляцію фізіологічним розчином; 6 - інтактна група. 3 метою раціональної подачі одержаних даних і їх інтерпретації умовно виділяли ранній (23-я, 30-а доби експерименту) та пізній (36-а і 44-а доби після початку експерименту) періоди розвитку алергічного запального процесу в легенях.

Тварин виводили з експерименту шляхом передозування тіопенталового наркозу згідно зі встановленими термінами (на 23-ю, 30-у, 36-у і 44-у доби експерименту). Гістологічні зрізи забарвлювали гематоксиліном-еозином. Проводили імпрегнацію сріблом за методом Лейдлоу для виявлення ретикулярних та еластичних волокон, забарвлення за Масоном для оцінки організації колагенових волокон. Морфологічне дослідження отриманих зрізів проводили за допомогою світлового мікроскопа Primo Star (Zeiss, Німеччина) із системою фотодокументування. Досліджу-

вали дві групи венул: посткапілярні та м' язові. Визначали величину внутрішнього діаметра судин. Результати досліджень оброблені сучасними статистичними методами аналізу на персональному комп'ютері з використанням стандартного пакета програм Microsoft Office 2010 (Microsoft Excel) та "STATISTICA® for Windows 6.0" (StatSoft Inc., США, ліцензія 46 № AXXR712D833214FAN5). Гіпотезу про нормальність розподілу досліджуваних показників перевіряли з використанням критерію Шапіро - Уїлка та критерію узгодженості Колмогорова - Смирнова. Для перевірки гіпотези про належність двох незалежних вибірок до одного закону розподілу використовували критерій однорідності Колмогорова - Смирнова. Розраховували середні арифметичні (М) та стандартні похибки середньої $( \pm m)$. Статистичну значущість міжгрупових відмінностей за отриманими даними встановлювали за допомогою параметричного t-критерію Стьюдента ( $p^{*}$ ) та непараметричного U-критерію Уїтні - Манна ( $\left.{ }^{* *}\right)$. Отримані показники порівнювали між медіаною і міжквартильним розмахом Ме (Q1; Q3). Статистично значущими вважали відмінності між порівнюваними значеннями на рівні $95 \%(p<0,05)$.

Результати й обговорення. За результатами проведеного гістологічного аналізу було встановлено, що ГМЦР легень морських свинок представлено багатокомпонентною системою, що складається з таких ланок: артеріол, прекапілярів, капілярів, посткапілярних та м'язових венул. Посткапілярні венули утворюються шляхом злиття кількох кровоносних капілярів. У тварин інтактної групи посткапілярні венули ГМЦР легень представляють собою тонкостінні судини із середнім діаметром просвіту $(23,27 \pm 0,52)$ мкм, стінка яких складається з трьох оболонок. Шар ендотеліальних клітин в середньому 1 - 2 мкм товщиною. Середню оболонку утворює один шар плоских перицитів. Адвентиційна оболонка являє собою шар тонких колагенових волокон із ниткоподібними відростками фіброцитів. М'язові венули з'єднують посткапілярні венули з дрібними венами. У тварин інтактної групи діаметр їх просвіту

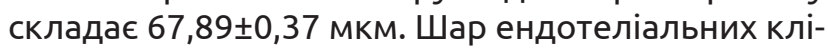
тин м' язових венул відносно товстий, до 3-4 мкм. Між ендотелієм та середньою оболонкою наявний тонкий шар колагенових і еластичних волокон. У середній оболонці з'являються один або два шари сплощених гладких міоцитів. Адвентицій утворює товстий шар колагенових волокон із фібробластами і відростками фіброцитів.

Після моделювання експериментального овальбумін-індукованого алергічного запалення в ГМЦР легень відбуваються процеси структурної перебудови ємнісної ланки. Спостерігаються ва- 
Огляди літератури, оригінальні дослідження, погляд на проблему, випадок з практики, короткі повідомлення зодилатація та повнокров'я, сладж-феномен еритроцитів посткапілярних та м'язових венул (рис. 1a, 1d), периваскулярні лімфоїдні скупчення

(рис. 1d). Ці зміни супроводжуються набряком і дезорганізацією волокнистих елементів сполучної тканини, яка оточує венули (рис. 2b, 2c).

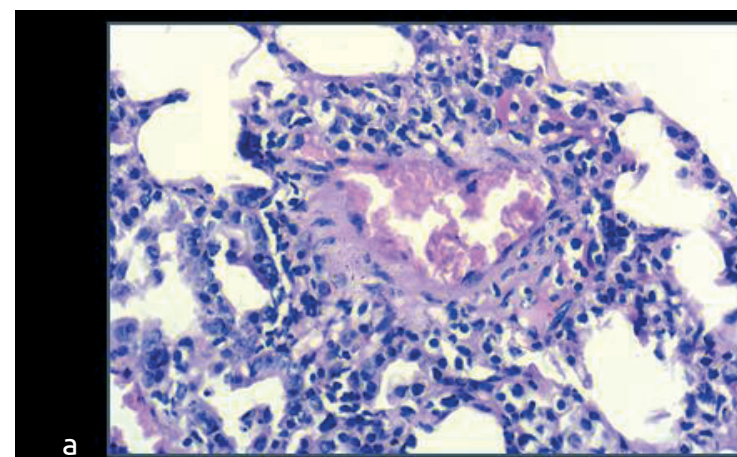

a

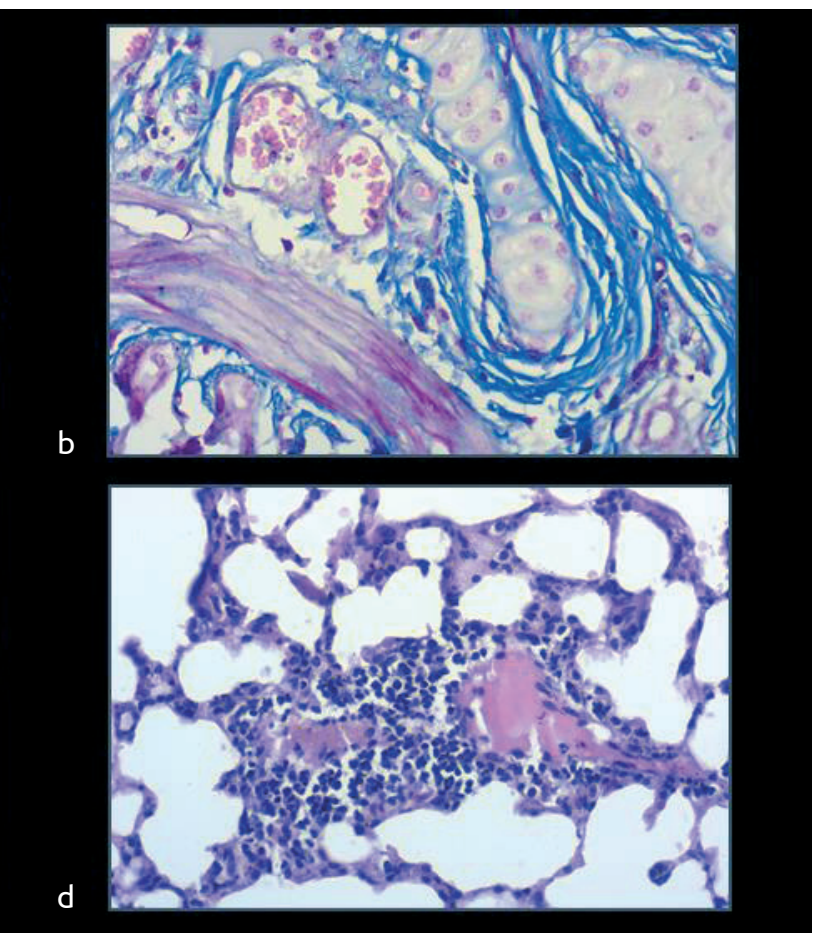

Рис. 1. Мікроскопічні зміни гемомікроциркуляторного русла легень морської свинки після сенсибілізації та аероалергізації овальбуміном на 23-ю (1a), 30-у (1b, 1c) та 44-у (1d) доби після початку експерименту. 1a - вазодилатація, повнокров'я, сладж-феномен еритроцитів м'язової венули; 1b, 1c - набряк і дезорганізація волокнистих елементів сполучної тканини навколо посткапілярних венул; 1d - вазодилатація, повнокров'я венул із периваскулярними лімфоїдними вузликами. Забарвлення: 1a, 1d - гематоксиліном і еозином; $1 \mathrm{~b}$ - за Масоном; 1c - імпрегнація сріблом за Лейдлоу. ×400.

Гістологічні особливості структури венул ГМЦР легень, які спостерігаються на світлооптичному рівні, мають своє кількісне морфометричне відображення.

Статистично значуща різниця між показниками діаметра просвіту посткапілярних венул у тварин інтактної та контрольної груп була відсутня, що свідчить про те, що сама процедура проведення експерименту не впливає на зміни морфометричних параметрів ємнісної ланки ГМЦР легень морської свинки. Після сенсибілізації та інгаляційної алергізації овальбуміном спостерігається тенденція до збільшення діаметра просвіту посткапілярних венул. Статистично значуща різниця між показниками діаметра просвіту посткапілярних венул у контрольній та експериментальних групах наявна вже в ранньому періоді розвитку алергічного запалення, з 23-ї доби спостереження (рис. 2).

Так, у 1-й експериментальній групі середній діаметр просвіту посткапілярних венул складає $(46,01 \pm 0,61)$ мкм, що у 1,7 раза більше, ніж анало- гічний показник у контрольній групі. Зберігається вазодилатація і на 30-у добу спостереження в 2-й експериментальній групі, в тварин якої середній діаметр просвіту посткапілярних венул складає $(43,22 \pm 0,51)$ мкм, що у 1,6 раза більше контролю. В пізній період розвитку алергічного запалення в легенях морської свинки відмічено статистично значиме збільшення у 1,4 раза просвіту посткапілярних венул, порівняно з контролем, що виявляється у 3-ій експериментальній групі на 36-у добу спостереження - $(38,08 \pm 0,71)$ мкм (рис. 2).

При подальшому морфометричному аналізі ГМЦР легень морської свинки виявлено, що статистично значуща різниця між показниками діаметра просвіту м'язових венул у тварин інтактної та контрольної груп була відсутня, що свідчить про те, що сама процедура проведення експерименту не впливає на зміни морфометричних параметрів м'язових венул ГМЦР легень морської свинки. Після сенсибілізації та інгаляції овальбуміном спостерігається тенденція до збільшення діаметра просвіту м'язових венул (рис. 3). 
Огляди літератури, оригінальні дослідження, погляд на проблему, випадок з практики, короткі повідомлення

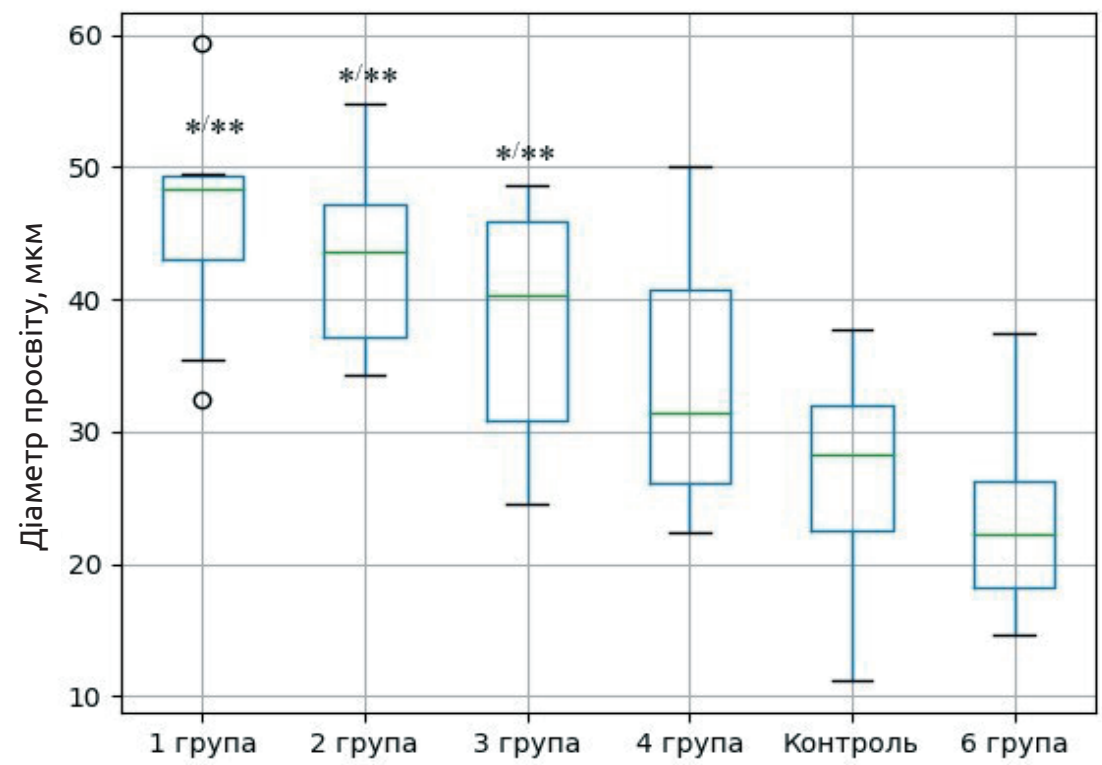

Рис. 2. Морфометричні показники посткапілярних венул гемомікроциркуляторного русла легень морських свинок після сенсибілізації овальбуміном.

Примітка. * - p<0,05 (t-критерій Стьюдента); ** - p<0,05 (U-критерій Уїтні - Манна) по відношенню до контролю. Ме (Q1; Q3). $\mathrm{M} \pm \mathrm{m} .(\mathrm{n}=8)$.

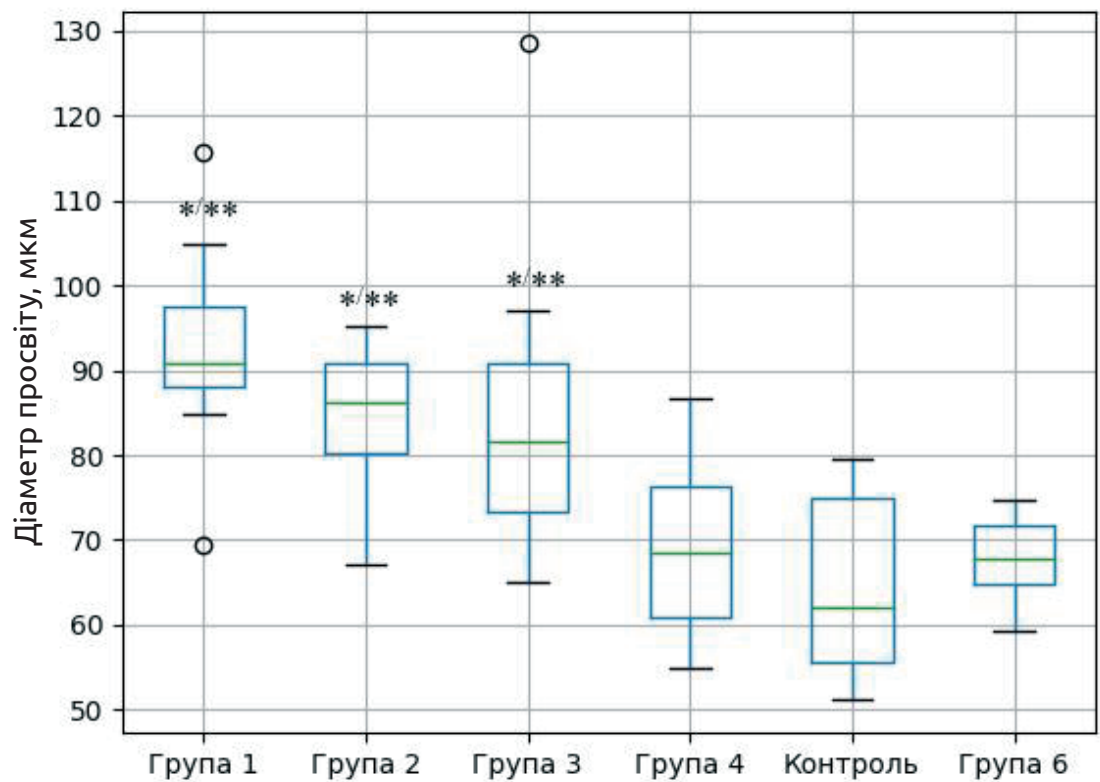

Рис. 3. Морфометричні показники м'язових венул гемомікроциркуляторного русла легень морських свинок після сенсибілізації овальбуміном.

Примітка. * - p<0,05 (t-критерій Стьюдента); ** - p<0,05 (U-критерій Уїтні-Манна) по відношенню до контролю; Ме (Q1; Q3). $\mathrm{M} \pm \mathrm{m}(\mathrm{n}=8)$.

При аналізі діаметра просвіту м'язових венул виявили, що він статистично значимо збільшується, порівняно з контролем, із 23-ї доби після початку експерименту й складає $(92,6 \pm 0,98)$ мкм, що перевищує показник контрольної групи у 1,4 раза. На 30-ту добу спостереження у тварин 2-ої експериментальної групи ця тенденція зберігається і діаметр просвіту м'язових венул збільшується майже у 1,3 раза, порівняно з тваринами контрольної групи, але дещо зменшується, порівняно з аналогічним показником у попередній групі (рис. 3). Така ж тенденція зберігається і протягом пізнього періоду розвитку алергічного запалення в легенях морських свинок. Так, у 3-ій експери- 
Огляди літератури, оригінальні дослідження, погляд на проблему, випадок з практики, короткі повідомлення ментальній групі середній діаметр просвіту м' язових венул складає $(86,09 \pm 1,44)$ мкм, коефіцієнт збільшення 1,3 порівняно з контролем. Тенденція до відновлення показників просвіту діаметрів як посткапілярних, так і м'язових венул, стає помітною на 44-ту добу спостереження в 4-ій експериментальній групі, але повної їх нормалізації не визначається.

У результаті сенсибілізації та інгаляції овальбуміном у легенях морських свинок розвивається алергічне запалення. Механізм запалення являє собою каскад процесів за участю великої різноманітності клітин, цитокінів і медіаторів, взаємодія яких і формує характерний запальний процес та викликане ним ремоделювання мікросудин і бронхів $[11,12]$. Судинний фактор відіграє важливу роль у розвитку алергічного процесу в легенях [13]. Ендотеліальні клітини експресують P-selectin, E-selectin, молекули міжклітинної адгезії-1 (ICAM-1) і молекули адгезії клітин крові (VCAM-1). 3 іншого боку, компоненти стінки судин (ендотелій, гладкі міоцити, фібробласти) $є$ мішенню для нейроендокринних [14] та імунних факторів [11] розвитку алергічного процесу в легенях. Отже, сенсибілізація та алергізація овальбуміном призводить до суттєвої структурно-функціональної перебудови судин ємнісної ланки ГМЦР легень морської свинки у вигляді повнокрів' я, вазодилатації, збільшення проникності судинної стінки, набряку та дезорганізації периваскулярної сполучної тканини. Подібна тенденція спостерігається в роботах інших дослідників [15-17]. Найсуттєвіші зміни відбуваються протягом раннього періоду розвитку алергічного запалення у посткапілярних венулах. Цей факт підтверджує максимальний коефіцієнт збільшення діаметра просвіту посткапілярних венул, що спостерігається в 1-ій експериментальній групі, порівняно з контролем, і становить 1,7, м'язових

\section{ЛІТЕРАТУРА}

1. Hrebniak M. P. Influence of industrial atmospheric pollution on the development of pathology of respiratory organs / M. P. Hrebniak, R. A. Fedorchenko // Pathologia. 2019. - Vol. 16 (1). - P. 81-86.

2. Сырцов В. К. Периферические органы иммунной системы / В. К. Сырцов, Н. А. Волошин, Е. Г. Алиева // Актуальні питання фармацевтичної і медичної науки та практики. - 2011. - Т. 24, № 1. - С. 8-11.

3. IL-17A, But Not IL-17F, Is Indispensable for Airway Vascular Remodeling Induced by Exaggerated Th17 Cell Responses in Prolonged Ovalbumin-Challenged Mice / S. Lu, H. Li, R. Gao [et al.] // J. Immunol. - 2015. - Vol. 194 (8). P. 3557-3566.

4. Hnatjuk M. S. Morphometric analysis remodeling vessels hemomicrocirculatory bed of jejunum at resections of liver / M. S. Hnatjuk, L. V. Tatarchuk // Rep. Morphology. 2018. - Vol. 24 (1). - P. 16-20.

венул - також в 1-ій експериментальній групі, становить 1,4. Вочевидь, виявлені зміни викликані реакцією на спазм резистивної та обмінної ланок гемомікроциркуляторного русла, що призводить на тлі гіпоксії до розладів мікроциркуляції в легенях із гіперреакцією мастоцитів, вміст секреторних гранул яких збільшує проникність стінки венул. Морфометричні зміни показників свідчать про те, що реалізація овальбумін-індукованого алергічного запального процесу в легенях відбувається за участі судинного компонента сполучної тканини легень і тривалість його перебігу не обмежується безпосереднім впливом антигену, а продовжується й після закінчення його дії.

Висновок. Сенсибілізація та інгаляційна алергізація овальбуміном призводить до структурної реорганізації у вигляді вазодилатації посткапілярних та м'язових венул гемомікроциркуляторного русла легень морських свинок, яка має односпрямований стадійний характер в залежності від діаметра судин і тривалості експерименту та $\epsilon$ проявом порушення відновно-адаптаційних процесів гемомікроциркуляції. Найбільш виражені зміни відбуваються протягом раннього періоду розвитку алергічного запального процесу в посткапілярних венулах гемомікроциркуляторного русла легень.

Перспективи подальших досліджень. Плануємо дослідження ультрамікроскопічних та імуногістохімічних змін компонентів судинної стінки гемомікроциркуляторного русла легень морських свинок при алергічному запаленні.

Фінансування. Дослідження проведено в рамках НДР Запорізького державного медичного університету на тему «Імуноморфологічні особливості внутрішніх органів при дії ендо- та екзогенних чинників на організм», № держреєстрації $0118 \cup 004250$.

Конфлікт інтересів. Відсутній.

5. Response of hemomicrocirculatory bed of internal organs on various external factors exposure based on the morphological research data / O. M. Pronina, M. M. Koptev, S. M. Bilash, G. A. Yeroshenko // World of Medicine and Biology. - 2018. - Vol. 63 (1). - P. 153-157.

6. Herasymiuk I. E. Features of remodeling of blood vessels of rat lungs in applying different methods of fluid resuscitation after general dehydration / I. E. Herasymiuk, M. O. Vatsyk // Bulletin of Problems Biology and Medicine. 2019. - Vol. 149 (1). - P. 272-276.

7. Небесна 3. М. Гістологічні та гістохімічні зміни легень при експериментальній термічній травмі / 3. М. Небесна, Г. А. Єрошенко // Світ медицини та біології. - 2015. - Т. 49, № 2. - С. 141-145.

8. Endothelial Sox17 promotes allergic airway inflammation / E. H. Ha, J.-P. Choi, H.-S. Kwon [et al.] // J. Allergy Clin. Immunol. - 2019. - Vol. 144 (2). - P. 561-573. 
Огляди літератури, оригінальні дослідження, погляд на

9. Reichard A. Endothelial Cells in Asthma / A. Reichard, K. Asosingh // Asthma - Biological Evidences ; in C. Pereira ed. - IntechOpen, 2019. - Available from: https:// www.intechopen.com/books/asthma-biological-evidences/endothelial-cells-in-asthma.

10. Back to the future: re-establishing guinea pig in vivo asthma models / M. Adner, B. J. Canning, H. Meurs [et al.] // Clin. Sci. - 2020. - Vol. 134 (11). - P. 1219-1242.

11. Lambrecht B. N. The immunology of asthma / B. N. Lambrecht, H. Hammad // Nat. Immunol. - 2014. Vol. 16 (1). - P. 45-56.

12. A guinea pig model of airway smooth muscle hyperreactivity induced by chronic allergic lung inflammation: contribution of epithelium and oxidative stress / L. H. C. Vasconcelos, M. da Conceição Correia Silva, A. C. Costa [et al.] // Front. Pharmacol. - 2019. - Vol. 9. - Article 1547. DOI: 0.3389/fphar.2018.01547.

13. Strain-specific differences in perivascular inflammation in lungs in two murine models of allergic лему випадок з практики, короткі повідомлення airway inflammation / B. Singh, K. Shinagawa, C. Taube [et al.] // Clin. Exp. Immunol. - 2005. - Vol. 141 (2). P. 223-229.

14. Popko S. S. Influence of pulmonary neuroendocrine cells on lung homeostasis / S. S. Popko, V. M. Evtushenko, V. K. Syrtsov // Zaporozhye Medical Journal. 2020. - Vol. 22 (4). - P. 568-575.

15. Albiflorin alleviates ovalbumin (OVA)-induced pulmonary inflammation in asthmatic mice / Z. Cai, J. Liu, H. Bian, J. Cai // Am. J. Transl. Res. - 2019. - Vol. 11 (12). P. 7300-7309.

16. Urtica dioica attenuates ovalbumin-induced inflammation and lipid peroxidation of lung tissues in rat asthma model / H. Zemmouri, O. Sekiou, S. Ammar [et al.] // Pharm. Biol. - 2017. - Vol. 55 (1). - P. 1561-1568.

17. Antwi A. O. Stigmasterol modulates allergic airway inflammation in guinea pig model of ovalbumin-induced asthma / A. O. Antwi, D. D. Obiri, N. Osafo // Mediators Inflamm. - 2017. - Vol. 2017. - 2953930.

\section{REFERENCES}

1. Hrebniak, M.P., \& Fedorchenko, R.A. (2019). Influence of industrial atmospheric pollution on the development of pathology of respiratory organs. Pathologia, 16 (1), 81-86. DOl:https://doi.org/10.14739/2310-1237.2019.1.166314

2. Syrcov, V.K., Voloshin, N.A., \& Alieva, E.G. (2011). Perifericheskie organy immunnoj sistemy [Peripheral organs of the immune system]. Aktualni pytannia farmatsevtychnoi i medychnoi nauky ta praktyky - Current Issues of Pharmaceutical and Medical Science and Practice, 24 (1), 8-11 [in Russian]. DOI: http://nbuv.gov.ua/UJRN/apfimntp_ 2011_24_1_4

3. Lu, S., Li, H., Gao, R., Gao, X., Xu, F., Wang, Q., \& Zhou, J. (2015). IL-17A, But Not IL-17F, Is indispensable for airway vascular remodeling induced by exaggerated Th17 cell responses in prolonged ovalbumin-challenged mice. J. Immunol., 194 (8), 3557-3566. DOI: https://doi.org/ 10.4049/jimmunol.1400829

4. Hnatjuk, M.S., \& Tatarchuk, L.V. (2018). Morphometric analysis remodeling vessels hemomicrocirculatory bed of jejunum at resections of liver. Rep. Morphology, 24 (1), 16-20. DOI: https://doi.org/10.31393/morphologyjournal-2018-24(1)-03

5. Pronina, O.M., Koptev, M.M., Bilash, S.M., \& Yeroshenko, G.A. (2018). Response of hemomicrocirculatory bed of internal organs on various external factors exposure based on the morphological research data. World of Medicine and Biology, 1 (63), 153-157. DOI: https://doi.org/ DOI 10.26.724 / 2079-8334-2018-1-63-153-157

6. Herasymiuk, I.E., \& Vatsyk, M.O. (2019). Features of remodeling of blood vessels of rat lungs in applying different methods of fluid resuscitation after general dehydration. Bulletin of Problems Biology and Medicine, 1 (2), 272-276. DOI: https://doi.org/10.29254/2077-4214-20191-2-149-272-276.

7. Nebesna, Z.M., \& Yeroshenko, G.A. (2015). Histolohichni ta histokhimichni zminy lehen pry eksperymentalnii termichni travmi [Histological and histochemical changes of the lungs after experimental thermal trauma]. World of Medicine and Biology, 2(49), 141-145 [in Ukrainian]. DOI: https://womab.com.ua/ua/smb-2015-02-2/5084

8. Ha, E.H., Choi, J.-P., Kwon, H.-S., Park, H.J., Lah, S.J., Moon, K.-A., \& Cho, Y.S. (2019). Endothelial Sox17 promotes allergic airway inflammation. J. Allergy Clin. Immunol., 144 (2), 561-573. DOI: https://doi.org/10.1016/j.jaci.2019.02.034.

9. Reichard, A., \& Asosingh, K. (2019). Endothelial Cells Asthma. Asthma - Biological Evidences. C. Pereira (Ed.). IntechOpen. DOI: 10.5772/intechopen.85110. Retrieved from: https://www.intechopen.com/books/asthma-biological-evidences/endothelial-cells-in-asthma.

10. Adner, M., Canning, B.J., Meurs, H., Ford, W., Ramos Ramírez, P., van den Berg, M.P.M., \& Dahlén, S.-E. (2020). Back to the future: re-establishing guinea pig in vivo asthma models. Clin. Sci., 134(11), 1219-1242. DOI: https://doi.org/10.1042/cs20200394

11. Lambrecht, B.N., \& Hammad, H. (2014). The immunology of asthma. Nat. Immunol., 16 (1), 45-56. DOI: https:// doi.org/10.1038/ni.3049

12. Vasconcelos, L.H.C., da Conceição Correia Silva, M., Costa, A.C., de Oliveira, G.A., de Souza, I.L.L., Queiroga, F.R., \& da Silva, B.A. (2019). A guinea pig model of airway smooth muscle hyperreactivity induced by chronic allergic lung inflammation: contribution of epithelium and oxidative stress. Front. Pharmacol., 9. DOI: https://doi.org/10.3389/ fphar.2018.01547

13. Singh, B., Shinagawa, K., Taube, C., Gelfand, E.W., \& Pabst, R. (2005). Strain-specific differences in perivascular inflammation in lungs in two murine models of allergic airway inflammation. Clin. Exp. Immunol., 141 (2), 223-229. DOI: https://doi.org/10.1111/j.1365-2249.2005.02841.x

14. Popko, S.S., Evtushenko, V.M., \& Syrtsov, V.K. (2020). Influence of pulmonary neuroendocrine cells on lung homeostasis. Zaporozhye Medical Journal, 22 (4), 568575. DOI: https://doi.org/10.14739/2310-1210.4.208411

15. Cai, Z., Liu, J., Bian, H., \& Cai, J. (2019). Albiflorin alleviates ovalbumin (OVA)-induced pulmonary inflammation in asthmatic mice. Am. J. Transl. Res., 11 (12), 73007309. DOI: https://www.ncbi.nlm.nih.gov/pmc/articles/ PMC6943473

16. Zemmouri, H., Sekiou, O., Ammar, S., El Feki, A., Bouaziz, M., Messarah, M., \& Boumendjel, A. (2017). Urtica 
Огляди літератури, оригінальні дослідження, погляд на проблему, випадок з практики, короткі повідомлення dioica attenuates ovalbumin-induced inflammation and lipid peroxidation of lung tissues in rat asthma model. Pharm. Biol., 55 (1), 1561-1568. DOI: https://doi.org/10.10 80/13880209.2017.1310905

17. Antwi, A.O., Obiri, D.D., \& Osafo, N. (2017). Stigmasterol modulates allergic airway inflammation in guinea pig model of ovalbumin-induced asthma. Mediators Inflamm. 2017, 2953930. DOI: https://doi.org/10.1155/2017/2953930

\title{
МОРФОЛОГИЧЕСКИЕ ИЗМЕНЕНИЯ СОСУДОВ ЕМКОСТНОГО ЗВЕНА ГЕМОМИКРОЦИРКУЛЯТОРНОГО РУСЛА ЛЕГКИХ МОРСКИХ СВИНОК, СЕНСИБИЛИЗИРОВАННЫХ ОВАЛЬБУМИНОМ
}

○С. С. Попко

\author{
Запорожский государственный медицинский университет
}

РЕЗЮМЕ. Актуальной проблемой современной медицины является реакция микрососудов легких при хронических аллергических заболеваниях дыхательной системы, так как именно от состояния сосудов гемомикроциркуляторного русла зависит полноценное функционирование тканей и клеток организма.

Цель - изучить морфологические изменения сосудов емкостного звена гемомикроциркуляторного русла легких морских свинок, сенсибилизированных овальбумином.

Материал и методы. С помощью гистологического, морфометрического и статистического методов изучили легкие 48 самцов морских свинок в условиях экспериментального овальбумин-индуцированного аллергического воспаления, которое моделировали путем трехкратной подкожной сенсибилизации и последующей 8-дневной интраназальной ингаляцией овальбумином. Для определения структурной и функциональной перестройки посткапиллярных и мышечных венул определяли величину внутреннего диаметра сосудов.

Результаты. Установлена общая закономерность реактивности емкостного звена гемомикроциркуляторного русла легких морских свинок при экспериментальном овальбумин-индуцированном аллергическом воспалении, заключающаяся в структурной и функциональной перестройке посткапиллярных и мышечных венул в виде увеличения диаметра их просвета и проницаемости их стенки. Более выраженные морфологические изменения выявлены в посткапиллярных венулах в раннем периоде развития аллергического воспаления, что подтверждает максимальный коэффициент увеличения диаметра просвета посткапиллярных венул, который наблюдается в первой экспериментальной группе, по сравнению с контролем, и составляет 1,7.

Выводы. Сенсибилизация и ингаляционная аллергизация овальбумином приводят к структурной реорганизации в форме вазодилатации посткапиллярных и мышечных венул гемомикроциркуляторного русла легких морских свинок, которая носит однонаправленный стадийный характер в зависимости от диаметра сосудов и продолжительности эксперимента и является проявлением нарушения восстановительно-адаптационных процессов гемомикроциркуляции. Наиболее выраженные изменения проявляются в течение раннего периода развития аллергического воспалительного процесса в посткапиллярных венулах.

КЛЮЧЕВЫЕ СЛОВА: венула; гемомикроциркуляция; экспериментальное аллергическое воспаление; легкое; овальбумин; морская свинка.

\section{MORPHOLOGICAL CHANGES IN THE CAPACITIVE LINK OF THE HEMOMICROCIRCULATORY BED OF LUNG OF GUINEA PIGS SENSITIZED WITH OVALBUMIN}

\author{
Zaporizhzhia State Medical University
}

@S. S. Popko

SUMMARY. An urgent issue in medicine today is the reaction of lungs microvessels with chronic respiratory allergic diseases, because the full functioning of tissues and cells depends on the microvessels.

The aim - to study the morphological changes in the vessels of the capacitive link of the microcirculatory bed of the lung of guinea pigs sensitized with ovalbumin.

Material and Methods. We have studied the lung of 48 guinea pigs, using histological and morphometric methods, under conditions of experimental ovalbumin-induced allergic inflammation, simulated by three times subcutaneous sensitization and subsequent 8-day intranasal inhalation of ovalbumin. To assess the structural and functional state of postcapillary and muscular venules the inner diameter of the vessels was determined. 
Огляди літератури, оригінальні дослідження, погляд на проблему, випадок з практики, короткі повідомлення

Results. A general regularity of the reactivity of the capacitive link of the hemomicrocirculatory bed of guinea pig lungs in experimental ovalbumin-induced allergic inflammation was established, consisted in the restructuring of postcapillary and muscle venules such as an increase in the diameter of their lumen and the permeability of their wall. More pronounced morphological changes were found in postcapillary venules in the early period of allergic inflammation, confirmed with the magnification factor, showed increase in the diameter of the lumen of postcapillary venules (1.7) in the first experimental group compared to the control.

Conclusions. Sensitization and inhalation allergization with ovalbumin leads to structural reorganization-vasodilation of the postcapillary and muscle venules of guinea pigs lungs, depended on the diameter of the vessels and the experiment duration and is a manifestation of a violation of the recovery and adaptation processes of microcirculation. The most pronounced changes appear during the early period of allergic inflammation in the postcapillary venules.

KEY WORDS: venule; microcirculation; experimental allergic inflammation; lung; ovalbumin; guinea pig.

Отримано 12.02.2021 